\title{
CALCIFIC TENDINOPATHY: CALCIUM DEPOSIT MORPHOLOGY DIRECTLY AFFECTS PAIN AND FUNCTION OF THE SHOULDER
}

\author{
Gordana Cesarec ${ }^{1,2}$, Sunčica Martinec ${ }^{1,2}$ and Nikola Čičak ${ }^{3,4}$ \\ ${ }^{1}$ Krapinske Toplice Special Hospital for Medical rehabilitation, Krapinske Toplice, Croatia; \\ ${ }^{2}$ Faculty of Medicine, Josip Juraj Strossmayer University of Osijek, Osijek, Croatia; \\ ${ }^{3}$ Akromion Special Hospital for Orthopedic Surgery, Krapinske Toplice, Croatia; \\ ${ }^{4}$ School of Medicine, University of Split, Split, Croatia
}

\begin{abstract}
SUMMARY - The aim of this study was to determine conventional ultrasonography characteristics of calcium deposits in patients diagnosed with calcific tendinopathy, to determine vascularization around deposits by power Doppler, and to compare morphological and power Doppler findings with clinical findings by use of two questionnaires. Pain and function were evaluated using the visual analog scale and two questionnaires, Constant Shoulder Score and Oxford Shoulder Score. All subjects underwent ultrasonography examination and evaluation of vascularization (flow) along calcium deposit using power Doppler. Fifty-one subjects were included in the study. The $\chi^{2}$-test, a non-parametric statistics method was used because of the categorical type of variables. The level of statistical significance was set at $\mathrm{p}<0.05$. In the inactive phase, calcium deposit was shown as a hyperechoic focal point with dorsal acoustic shadow and negative power Doppler finding, whereas in the resorptive phase it appeared as fragmented irregular hyperechoic focal points with positive power Doppler findings. This study showed the patients with fragmented, cloudy calcification to have statistically significantly worse results on functional questionnaires and more positive power Doppler findings (grades II and III) and to experience stronger pain (visual analog scale 8-10). Upon defining the stage of calcific tendinopathy, the method of treatment can be determined and further course of the disease predicted. Defining the stage of calcification precisely helps avoid unnecessary and long-lasting physical therapy while introducing an effective treatment option, depending on the stage of the disease.
\end{abstract}

Key words: Calcific tendinopathy; Shoulder; Morphology; Ultrasonography; Power Doppler

\section{Introduction}

Calcific tendinopathy of the shoulder is characterized by the presence of one or multiple deposits of calcium hydroxyapatite in tendons of the rotator cuff. It is a common cause of shoulder pain in adults. It is considered as an active cell-mediated process, although accurate pathophysiology remains unclear ${ }^{1}$. One of the

Correspondence to: Gordana Cesarec, $M D$, Krapinske Toplice Special Hospital for Medical Rehabilitation, Gajeva 2, HR-49217 Krapinske Toplice, Croatia

E-mail: gordana.cesarec1@gmail.com

Received October 31, 2018, accepted December 19, 2019 newer theories describes metaplastic transformation of tenocytes, in other words, differentiation of stem cells into chondrocytes and osteoblasts instead of tenocytes under the influence of increased bone morphogenetic protein 2 (BMP-2) $)^{2,3}$. Calcific tendinopathy is easily diagnosed by conventional radiography and ultrasonography (US) ${ }^{4}$. US examination is a fundamental tool for diagnosis and treatment, especially for determination of the localization, size and morphology of the deposit. There is no generally accepted classification of the morphology of calcium deposits. Farin et al. classify deposits into 3 types: hyperechoic focus with a well-defined shadow; hyperechoic focus with a faint 
shadow; and hyperechoic focus with no shadow ${ }^{5}$ Chiou et al. classify deposits into four forms: arch-shaped (hyperechoic arch with a clear shadow); fragmented or puncture-shaped (at least two separate echogenic areas with or without shadows); nodular-shaped (echogenic node without shadowing); and cystic-shaped (a thick echogenic wall with an anechogenic area or layered contents) $)^{6}$. Power Doppler examination during the nodular or cystic phase shows increased vascularity around the deposit that correlates well with the histopathologic findings reported in the study by Uhthoff $e t$ al., which showed that during the phase of reabsorption deposits were surrounded by phagocytes, and at the same time there was proliferation of vascular channels around the deposits ${ }^{7,8}$.

The aim of our study was to determine US morphology of calcium deposits in patients diagnosed with calcific tendinopathy of the rotator cuff. Furthermore, we attempted to assess the effect of this morphology, visualized by US and power Doppler, on pain and function of the shoulder.

\section{Subjects and Methods}

The study included 51 subjects (age range 20-60 years) with unilateral calcific tendinopathy. The inclusion criteria were US and radiological diagnosis of calcific tendinopathy, and age range between 20 and 60 years. Exclusion criteria were calcific tendinopathy of the opposite shoulder; rupture of the rotator cuff of either shoulder; inflammatory rheumatic disease; appearance of pain in the shoulder during physiological movements of the cervical spine; history of subluxation or dislocation; intra-articular or periarticular injection in the last 3 months; physical therapy in the last 6 weeks; fracture of the shoulder joint; open wounds or skin infection in the shoulder area; and simultaneous inclusion in other researches. Control group consisted of asymptomatic healthy contralateral shoulder.

The following data were collected from all study subjects: age, gender, dominant arm, pain during the night and pain estimation using the visual analog scale (VAS). VAS consists of a straight line with equal $1-\mathrm{cm}$ intervals, from 0 "without pain" to 10 "worst conceivable pain"'.

Estimation and recordings of pain were performed by the subjects themselves. Pain was estimated in three categories: mild pain ranging from 1 to 3 , moderate pain from 4 to 7 , and severe pain from 8 to 10 .

Subjects filled-in the Oxford Shoulder Score (OSS) that consists of 12 questions, with grades ranging from 0 to 48, where 0 represents maximal disability, and score 48 no disability ${ }^{10}$. The Constant Shoulder Score (CSS) consists of 8 questions related to pain, activities of daily living, strength of abduction and range of motion ${ }^{11-13}$. The score unifies subjective and objective estimate into one result. Objective parameters included movement and strength (65 points), and subjective parameters included pain and impact on activities of daily living (35 points). A higher score indicated lower pain level and better function of the shoulder. The overall result was seen as difference between a healthy and affected shoulder. Standard radiograph in the anteroposterior (AP) view and recordings in the internal and external rotation were performed on the affected shoulder and standard AP radiograph on the contralateral shoulder.

There are various radiological classifications based on the size and morphology of calcium deposits and phase of the disease. In this study, radiological classification based on the size of deposit, presented by Bosworth, was used: small $<0.5 \mathrm{~cm}$, medium $0.5-1.0 \mathrm{~cm}$, and large $>1.5 \mathrm{~cm}^{14}$.

The US examination of both shoulders was taken using Siemens-Acuson X500 with $5-13 \mathrm{MHz}$ frequency transducer in $\mathrm{B}$ mode and power Doppler for semi-quantification of the flow. US examination was carried out according to the European Society of Musculoskeletal Radiology (ESSR) Ultrasound Group Protocols ${ }^{15}$. Classification based on deposit US morphology was used: type I, arch-shaped; type II, fragmented, cloudy-shaped; and type III, nodular-shaped.

Power Doppler was used to detect, display and quantify flow rate in tendons and subacromial-subdeltoid bursa (SASD). Semi-quantification of power Doppler findings was as follows: grade 0 - no signal; grade I - low flow, Doppler signal found in one vessel; grade II - moderate flow, few (3-6) signals; and grade III - strong flow, more than 6 Doppler signals found.

\section{Ethics}

Permission to conduct this research was granted by the Ethics Committee of Krapinske Toplice Special Hospital for Medical Rehabilitation. This research was part of a larger research entitled Impact of Morphol- 
Table 1. Semi quantification of power Doppler findings - visual analog scale (VAS)

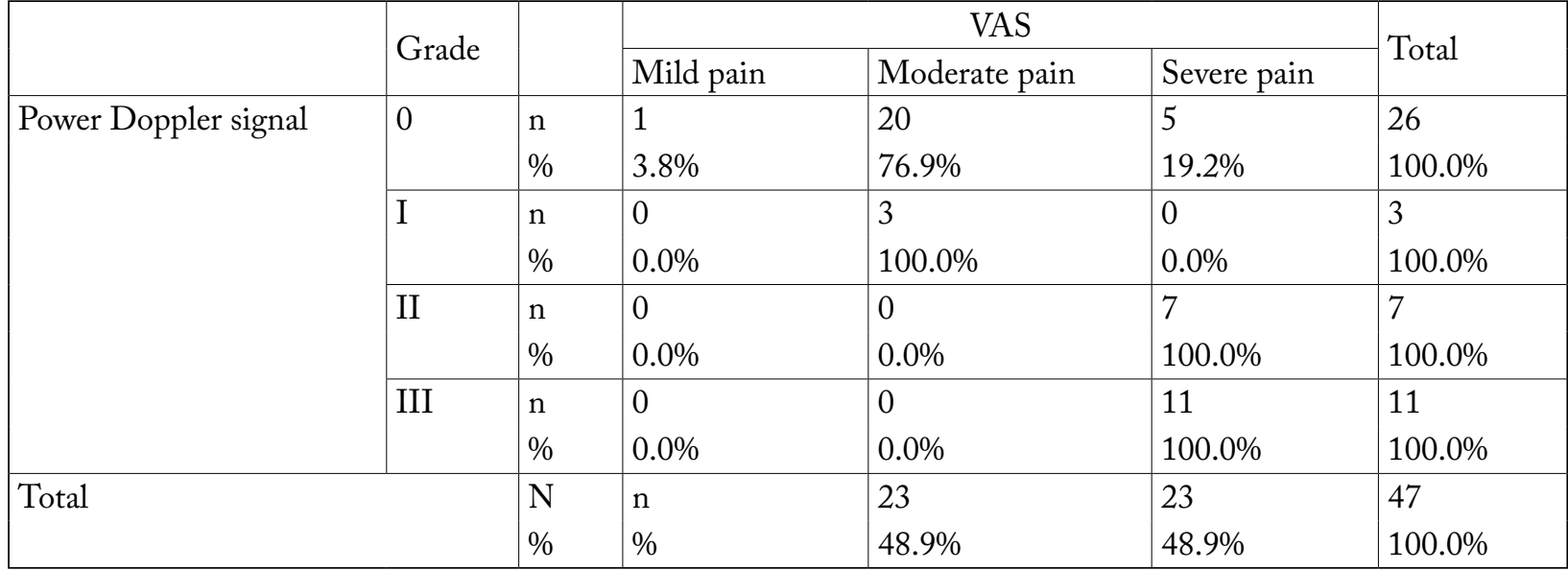

$\chi^{2}=31.124 ; \mathrm{df}=6 ; \mathrm{p}<0.001$

ogy of Calcified Deposits within the Rotator Cuff on Pain and Function of the Shoulder.

\section{Statistics}

Descriptive statistics was calculated for each individual variable and presented in tables. The sample was divided into subclasses in accordance with the research question, and then testing of differences between subclasses was conducted. Given the variables of the categorical type, $\chi^{2}$-test was used as a method of nonparametric statistics. The level of statistical significance was set at $\mathrm{p}<0.05$.

The results were processed using the SPSS 19.0 statistical package.

\section{Results}

The study included 51 subjects aged 20-59 diagnosed with unilateral calcific tendinopathy. Subjects who had calcium deposits of various morphology were placed in a separate group whose results were not interpreted. Due to this, the final number of study subjects was 47 . The sample was equally divided based on the subject answers to the question about the dominant hand; $49 \%$ of subjects gave affirmative and $51 \%$ negative answer to this question. Pain during the night was experienced by $94.1 \%$ of study subjects and only three subjects (5.9\%) did not experience pain at night. Most subjects indicated severe pain on the VAS (49.0\%). Almost an equal number of subjects reported moderate pain and only $3.9 \%$ (two subjects) no pain at all.
In more than half of the subjects (51.0\%), the size of deposits ranged from 0.5 to $1.5 \mathrm{~cm}, 41.2 \%$ had deposits greater than $1.5 \mathrm{~cm}$, and only $7.8 \%$ smaller than $0.5 \mathrm{~cm}$. Most of the subjects $(41.2 \%)$ had fragmented, clouded deposits, $31.4 \%$ had arch-shaped deposits, and $27.5 \%$ had nodular-shaped deposits. Of all study subjects, 3.92\% had both arch-shaped and fragmented calcified deposits, 3.92\% had both fragmented and nodular-shaped deposits, and 1.96\% had both arch-shaped and nodular-shaped deposits. Results of power Doppler signal were as follows: $66.7 \%$ had Doppler signal in the SASD bursa, $29.4 \%$ had none, and $45.1 \%$ had positive power Doppler signal along the calcified deposit.

Difference between patients with different levels of pain on the VAS was statistically significant at the level $<1 \%\left(\chi^{2}=31.124 ; \mathrm{df}=6 ; \mathrm{p}<0.001\right)$. Doppler signal grade 0 was most common in subjects with moderate pain and Doppler signal grade III in subjects with severe pain (Table 1 ).

Difference in the level of pain between patients with three different types of calcified deposits was statistically significant at the level $<1 \%\left(\chi^{2}=30.929 ; \mathrm{df}=4\right.$; $\mathrm{p}<0.001)$. Moderate pain occurred most frequently in arch-shaped and nodular deposits, and severe pain in fragmented deposits (Table 2). According to the results of the VAS questionnaire, difference between subjects with dissimilar deposit sizes was not statistically significant $\left(\chi^{2}=1.696 ; \mathrm{df}=6 ; \mathrm{p}=0.945\right)$ (Table 3 ).

Functional scores showed worse results of OSS and CSS in fragmented deposits (Table 4). Difference between patients with three different types of deposits in 
Table 2. Visual analog scale (VAS) according to calcified deposit ultrasonography (US) morphology

\begin{tabular}{|c|c|c|c|c|c|}
\hline \multirow{2}{*}{\multicolumn{2}{|c|}{ VAS }} & \multicolumn{4}{|c|}{ US morphology } \\
\hline & & Arch-shaped & Fragmented & Nodular & Total \\
\hline $\begin{array}{l}\text { Mild pain } \\
\text { (VAS 1-3) }\end{array}$ & $\begin{array}{l}\mathrm{n} \\
\mathrm{\%}\end{array}$ & $\begin{array}{l}2 \\
66.7 \%\end{array}$ & $\begin{array}{l}0 \\
0.0 \%\end{array}$ & $\begin{array}{l}1 \\
33.3 \%\end{array}$ & \begin{tabular}{|l|}
3 \\
$100.0 \%$
\end{tabular} \\
\hline $\begin{array}{l}\text { Moderate pain } \\
\text { (VAS 4-7) }\end{array}$ & $\begin{array}{l}\mathrm{n} \\
\%\end{array}$ & $\begin{array}{l}13 \\
61.9 \%\end{array}$ & $\begin{array}{l}1 \\
4.8 \%\end{array}$ & $\begin{array}{l}7 \\
33.3 \%\end{array}$ & $\begin{array}{l}21 \\
100.0 \%\end{array}$ \\
\hline $\begin{array}{l}\text { Severe pain } \\
\text { (VAS 8-10) }\end{array}$ & $\begin{array}{l}\mathrm{n} \\
\%\end{array}$ & $\begin{array}{l}0 \\
0.0 \%\end{array}$ & $\begin{array}{l}18 \\
78.3 \%\end{array}$ & $\begin{array}{l}5 \\
21.7 \%\end{array}$ & \begin{tabular}{|l|}
23 \\
$100.0 \%$
\end{tabular} \\
\hline Total & $\begin{array}{l}\mathrm{N} \\
\%\end{array}$ & $\begin{array}{l}15 \\
31.9 \%\end{array}$ & $\begin{array}{l}19 \\
40.4 \%\end{array}$ & $\begin{array}{l}13 \\
27.7 \%\end{array}$ & $\begin{array}{l}47 \\
100.0 \%\end{array}$ \\
\hline
\end{tabular}

$\chi^{2}=30.929 ; \mathrm{df}=4 ; \mathrm{p}<0.001$

Table 3. Visual analog scale (VAS) according to calcified deposit x-ray size

\begin{tabular}{|c|c|c|c|c|c|c|}
\hline \multirow{2}{*}{\multicolumn{2}{|c|}{ VAS }} & \multicolumn{4}{|c|}{$\mathrm{X}$-ray size } & \multirow{3}{*}{\begin{tabular}{|l} 
Total \\
2 \\
$100.0 \%$
\end{tabular}} \\
\hline & & \multirow{2}{*}{\begin{tabular}{|l|}
$>1$ \\
calcified deposit \\
0 \\
$0.0 \%$
\end{tabular}} & \multirow{2}{*}{$\begin{array}{l}\leq 0.5 \mathrm{~cm} \\
0 \\
0.0 \%\end{array}$} & \multirow{2}{*}{\begin{tabular}{|l}
$0.5-1.5 \mathrm{~cm}$ \\
1 \\
$50.0 \%$
\end{tabular}} & \multirow{2}{*}{$\begin{array}{l}>1.5 \mathrm{~cm} \\
1 \\
50.0 \%\end{array}$} & \\
\hline Mild pain & $\begin{array}{l}\mathrm{n} \\
\%\end{array}$ & & & & & \\
\hline $\begin{array}{l}\text { Moderate } \\
\text { pain }\end{array}$ & $\begin{array}{l}\mathrm{n} \\
\%\end{array}$ & $\begin{array}{l}1 \\
4.3 \%\end{array}$ & $\begin{array}{l}2 \\
8.7 \%\end{array}$ & $\begin{array}{l}12 \\
52.2 \%\end{array}$ & $\begin{array}{l}8 \\
34.8 \%\end{array}$ & \begin{tabular}{|l}
23 \\
$100.0 \%$
\end{tabular} \\
\hline Severe pain & $\begin{array}{l}\mathrm{n} \\
\%\end{array}$ & \begin{tabular}{|l|}
0 \\
$0.0 \%$
\end{tabular} & $\begin{array}{l}2 \\
8.0 \%\end{array}$ & $\begin{array}{l}12 \\
48.0 \%\end{array}$ & $\begin{array}{l}11 \\
44.0 \%\end{array}$ & \begin{tabular}{|l|}
25 \\
$100.0 \%$
\end{tabular} \\
\hline Total & $\begin{array}{l}\mathrm{N} \\
\%\end{array}$ & $\begin{array}{l}1 \\
2.0 \%\end{array}$ & $\begin{array}{l}4 \\
8.0 \%\end{array}$ & $\begin{array}{l}25 \\
50.0 \%\end{array}$ & $\begin{array}{l}20 \\
40.0 \%\end{array}$ & $\begin{array}{l}50 \\
100.0 \%\end{array}$ \\
\hline
\end{tabular}

$\chi^{2}=1.696 ; \mathrm{df}=6 ; \mathrm{p}=0.945$

Table 4. Oxford Shoulder Score according to calcifed deposit ultrasonography (US) morphology

\begin{tabular}{|c|c|c|c|c|c|c|}
\hline & \multicolumn{4}{|c|}{ US morphology } \\
\hline & & & Arch-shaped & Fragmented (clouded) & Nodular & Total \\
\hline \multirow{4}{*}{$\begin{array}{l}\text { Oxford Shoulder Score } \\
\text { - categorized according } \\
\text { to results }\end{array}$} & 0-19 & $\begin{array}{l}\mathrm{n} \\
\%\end{array}$ & $\begin{array}{l}2 \\
9.1 \% \\
\end{array}$ & $\begin{array}{l}17 \\
77.3 \%\end{array}$ & \begin{tabular}{|l|}
3 \\
$13.6 \%$ \\
\end{tabular} & \begin{tabular}{|l|}
22 \\
$100.0 \%$ \\
\end{tabular} \\
\hline & $20-29$ & $\begin{array}{l}\mathrm{n} \\
\%\end{array}$ & \begin{tabular}{|l|}
5 \\
$50.0 \%$
\end{tabular} & $\begin{array}{l}2 \\
20.0 \%\end{array}$ & \begin{tabular}{|l|}
3 \\
$30.0 \%$ \\
\end{tabular} & \begin{tabular}{|l|}
10 \\
$100.0 \%$ \\
\end{tabular} \\
\hline & $30-39$ & $\begin{array}{l}\mathrm{n} \\
\%\end{array}$ & $\begin{array}{l}6 \\
50.0 \%\end{array}$ & \begin{tabular}{|l|}
0 \\
$0.0 \%$
\end{tabular} & $\begin{array}{l}6 \\
50.0 \%\end{array}$ & \begin{tabular}{|l|}
12 \\
$100.0 \%$
\end{tabular} \\
\hline & $40-48$ & $\begin{array}{l}\mathrm{n} \\
\%\end{array}$ & $\begin{array}{l}2 \\
66.7 \%\end{array}$ & \begin{tabular}{|l|}
0 \\
$0.0 \%$
\end{tabular} & $\begin{array}{l}1 \\
33.3 \%\end{array}$ & \begin{tabular}{|l}
3 \\
$100.0 \%$
\end{tabular} \\
\hline \multicolumn{2}{|l|}{ Total } & $\begin{array}{l}\mathrm{N} \\
\%\end{array}$ & $\begin{array}{l}15 \\
31.9 \%\end{array}$ & $\begin{array}{l}19 \\
40.4 \%\end{array}$ & $\begin{array}{l}13 \\
27.7 \%\end{array}$ & \begin{tabular}{|l}
47 \\
$100.0 \%$
\end{tabular} \\
\hline
\end{tabular}

$\chi^{2}=25.250 ; \mathrm{df}=6 ; \mathrm{p}<0.001$ 
Table 5. Constant Shoulder Score according to calcified deposit ultrasonography (US) morphology

\begin{tabular}{|l|l|l|l|l|l|l|}
\hline \multicolumn{2}{|c}{} & \multicolumn{5}{c|}{ US morphology } \\
\cline { 3 - 7 } \multicolumn{2}{|c|}{} & Arch- shaped & $\begin{array}{l}\text { Fragmented } \\
\text { (clouded) }\end{array}$ & Nodular & Total \\
\hline $\begin{array}{l}\text { Constant Shoulder } \\
\text { Score - difference }\end{array}$ & Excellent & $\mathrm{n}$ & 3 & 0 & 1 & 4 \\
& & $\%$ & $75.0 \%$ & $0.0 \%$ & $25.0 \%$ & $100.0 \%$ \\
\cline { 2 - 7 } & Good & $\mathrm{n}$ & 9 & 0 & 5 & 14 \\
& & $\%$ & $64.3 \%$ & $0.0 \%$ & $35.7 \%$ & $100.0 \%$ \\
\cline { 2 - 7 } & Fair & $\mathrm{n}$ & 3 & 0 & 0 & 3 \\
& & $\%$ & $100.0 \%$ & $0.0 \%$ & $0.0 \%$ & $100.0 \%$ \\
\cline { 2 - 7 } & Poor & $\mathrm{n}$ & 0 & 19 & 7 & 26 \\
& & $\%$ & $0.0 \%$ & $73.1 \%$ & $26.9 \%$ & $100.0 \%$ \\
\hline Total & $\mathrm{N}$ & 15 & 19 & 13 & 47 \\
& & & $31.9 \%$ & $40.4 \%$ & $27.7 \%$ & $100.0 \%$ \\
\hline
\end{tabular}

$\chi^{2}=36.098 ; \mathrm{df}=6 ; \mathrm{p}<0.001$

the CSS was statistically significant at the level $<1 \%$ $\left(\chi^{2}=36,098 ; \mathrm{df}=6 ; \mathrm{p}<0.001\right)$. "Excellent" and "good" result was most commonly observed in patients with archshaped deposits, whereas "poor" result was mostly seen in those with fragmented, cloudy deposits (Table 5).

The power Doppler signal grade 0 was most frequently recorded in arch-shaped and nodular-shaped deposits, and power Doppler signal grades II and III in fragmented deposits $\left(\chi^{2}=35.68 ; \mathrm{df}=9 ; \mathrm{p}<0.001\right)$.

\section{Discussion}

Chiou et al. report that fragmented deposits are associated with acute worsening of pain and spontaneous resolution of symptoms, which is consistent with the results of the present study ${ }^{6}$. In the study conducted by Le Goff and Berthelot, positive power Doppler signal within the calcific deposit and subacromial-subdeltoid bursa widening were US features strongly associated with pain. Larger calcifications were also more symptomatic ${ }^{16}$. Our study did not demonstrate that larger calcifications led to stronger pain.

Pain was arbitrarily evaluated in three categories: mild pain - score 1 to 3 , moderate pain - score 4 to 7 , and severe pain - score 8 to 10 , which is accepted definition in similar studies. All subjects were examined on the same device by the same examiner, with the maximally standardized technique and without the inter-observer variety. The same US probe was used in all subjects, and all parameters (gain, US focusing, dy- namic range, etc.) were the same on all examinations. In the literature, there are some researches on rheumatoid arthritis where multiple quantitative Doppler indicators such as the resistance index (RI), peak systolic velocity (PSV) and end-diastolic velocity (EDV) were analyzed to determine flow through the synovial membrane. Since we did not have positive Doppler signal in any of the tendons or it was too weak to quantify and measure flow indicators, we abandoned measuring quantitative Doppler indicator and decided for semi-quantification of Doppler findings.

On the current US devices, there is almost no difference between power Doppler and color Doppler. Although it would be logical for power Doppler to show better flows in small blood vessels, some studies have shown that color Doppler is better than power Doppler to evaluate blood supply of the joints in rheumatoid arthritis ${ }^{17}$.

What was not foreseen in this research was that individual subjects would have more than one calcified deposit with different morphology. These subjects were placed in a separate group and their results were not interpreted.

This research revealed that patients with fragmented, cloudy calcification achieved statistically significantly worse results on functional questionnaires, had more positive findings of power Doppler (grades II and III) and experienced stronger pain (VAS 8-10).

Conservative treatment is still the main method of treatment. Using anti-inflammatory drugs, physical 
therapy interventions and corticosteroid injections lead to improvement in most of the patients.

Monitoring of the development of calcified deposits by power Doppler as an indicator of the inflammatory process in the tendon and of spontaneous resorption helps predict the duration of symptoms and make decision on the way of treatment.

Defining the stage of calcific tendinopathy will determine the mode of treatment and prognosis of further course of the disease. By precisely defining the stage of deposits, unnecessary long-lasting physical therapy will be avoided and effective treatment can be introduced depending on the stage of the disease. All these will contribute to better understanding of the evolution of calcific tendinopathy.

\section{References}

1. Suzuki K, Potts A, Anakwenze O, Singh A. Calcific tendinitis of the rotator cuff: management options. J Am Acad Orthop Surg. 2014;22(11):707-17. doi: 10.5435/JAAOS-22-11-707.

2. Rui YF, Lui PP, Ni M, Chan LS, Lee YW, Chan KM. Mechanical loading increased BMP-2 expression which promoted osteogenic differentiation of tendon-derived stem cells. J Orthop Res. 2011;29(3):390-6. doi: 10.1002/jor.21218.

3. Rui YF, Lui PP, Chan LS, Chan KM, Fu SC, Li G. Does erroneous differentiation of tendon-derived stem cells contribute to the pathogenesis of calcifying tendinopathy. Chin Med J (Engl). 2011;124(4):606-10.

4. Chianca V, Albano D, Messina C, et al. Rotator cuff calcific tendinopathy: from diagnosis to treatment. Acta Biomed. 2018;89:186-96. doi:10.23750/abm.v89i1-S.7022.

5. Farin PU, Jaroma H, Soimakallio S. Rotator cuff calcifications: treatment with US-guided technique. Radiology. 1995;195 (3):841-3. doi: 10.1148/radiology. 195.3.7754018.

6. Chiou HJ, Chou YH, Wu JJ, Hsu CC, Huang DY, Chang CY. Evaluation of calcific tendonitis of the rotator cuff - role of color doppler ultrasonography.J Ultrasound Med. 2002;21:28995. doi:10.7863/jum.2002.21.3.289.

7. Chiou HJ, Chou YH, Wu JJ, Huang TF, Ma HL, Hsu CC, Chang CY. The role of high-resolution ultrasonography in management of calcific tendonitis of the rotator cuff. Ultrasound Med Biol. 2001;27(6):735-43. doi: 10.1016/S03015629(01) 00353-2.

8. Uhthoff H, Sarkar K, Maynard J. Calcifying tendinitis: a new concept of its pathogenesis. Clin Orthop Relat Res. 1976; 118:164-8.

9. Hawker GA, Mian S, Kendzerska T, French M. Measures of adult pain: Visual Analog Scale for Pain (VASPain), Numeric Rating Scale for Pain (NRS Pain), McGill Pain Questionnaire (MPQ), Short-Form McGill Pain Questionnaire (SF-MPQ), Chronic Pain Grade Scale (CPGS), Short Form-36 Bodily Pain Scale (SF-36 BPS), and Measure of Intermittent and Constant Osteoarthritis Pain (ICOAP). Arthritis Care Res. 2011;63:S240-S252. doi: 10.1002/acr.20543.

10. Dawson J, Fitzpatrick R, Carr A. Questionnaire on the perceptions of patients about shoulder surgery. J Bone Joint Surg Br. 1996;78(4):593-600.

11. Constant CR, Murley AH. A clinical method of functional assessment of the shoulder. Clin Orthop Relat Res. 1987;214: 160-4.

12. Fabre T, Piton C, Leclouerec G, Gervais-Delion F, Durandeau A. Entrapment of the suprascapular nerve. J Bone Joint Surg Br. 1999;81(3):414-9.

13. Sansone V, Maiorano E, Galluzzo A, Pascale. Calcific tendinopathy of the shoulder: clinical perspectives into the mechanisms, pathogenesis, and treatment. Ortop Res Rev. 2018;10: 63-72. doi:10.2147/ORR.S138225

14. Bosworth BM. Calcium deposits in the shoulder and subacromial bursitis: a survey of 12,122 cases. JAMA. 1941;116: 2477-82.

15. Naredo E, Aguado P, De Miguel E, et al. Painful shoulder: comparison of physical examination and ultrasonographic findings. Ann Rheum Dis. 2002;61:132-6.

16. Le Goff B, Berthelot J-M. Assessment of calcific tendonitis of rotator cuff by ultrasonography: comparison between symptomatic and asymptomatic shoulders. Joint Bone Spine. 2010; 77:258-63. doi:10.1016/j.jbspin.2010.01.012

17. Naredo E, Bonilla G, Gamero F, Uson J, Carmona L, Laffon A. Assessment of inflammatory activity in rheumatoid arthritis: a comparative study of clinical evaluation with grey scale and power Doppler ultrasonography. Ann Rheum Dis. 2005;64: 375-81. doi: 10.1136/ard.2004.023929 


\title{
Sažetak \\ KALCIFICIRAJUĆA TENDINOPATIJA: IZRAVNI UTJECAJ MORFOLOGIJE KALCIFIKATA NA BOL I FUNKCIJU RAMENA
}

\author{
G. Cesarec, S. Martinec i N. Čičak
}

Cilj istraživanja bio je utvrditi konvencionalne (B-prikaz) ultrazvučne karakteristike kalcifikata kod oboljelih od kalcificirajuće tendinopatije, odrediti jačinu vaskularizacije oko kalcifikata pomoću power Dopplera te usporediti morfološke i doplerske nalaze s kliničkim nalazom aktivnosti bolesti pomoću dva funkcijska upitnika. Bol i funkcija procijenjene su pomoću vizualne analogne ljestvice (visual analog scale, VAS) i dva uputnika: Constant Shoulder Score i Oxford Shoulder Score. Svi ispitanici bili su podvrgnuti ultrazvučnom pregledu i procjeni vaskularizacije (protoka) uz kalcifikat pomoću power Dopplera. U ovo istraživanje inicijalno je uključen 51 ispitanik. Rezultati su obrađeni pomoću statističkog paketa SPSS 19.0. Izračunata je deskriptivna statistika svake pojedine varijable. $\mathrm{S}$ obzirom na to da se radilo o varijablama kategorijalnog tipa primijenjena je metoda neparametrijske statistike, $\chi^{2}$-test. Dogovorena razina statističke značajnosti bila je $p<0,05$. U fazi mirovanja kalcifikat se prikazao kao hiperehogeno lučno žarište s dorzalno akustičnom sjenom i negativnim nalazom power Dopplera, dok se u resorptivnoj fazi prikazao kao oblačasta nepravilna hiperehogena žarišta s pozitivnim nalazom power Dopplera. Ovim istraživanjem se dokazalo da ispitanici s fragmentiranim, oblačastim kalcifikatom ostvaruju statistički značajno lošiji rezultat funkcijskih upitnika, imaju pozitivniji nalaz powver Dopplera (II. i III. stupanj) i jaču bol (VAS 8-10). Definiranjem stadija kalcificirajuće tendinopatije određuje se način liječenja te prognozira tijek bolesti. Točnim definiranjem stadija kalcifikata izbjeći će se nepotrebna dugotrajna fizikalna terapija, a ujedno omogućiti učinkovito liječenje ovisno o stadiju bolesti.

Ključne riječi: Kalcificirajuća tendinopatija; Rame; Morfologija; Ultrazvuk; Power Doppler 